\title{
Human Resource Management Practices on Organizational Performance in Libya Firm
}

\author{
Fathi M. A. ALDamoe ${ }^{1}$, Mohamd Yazam ${ }^{1} \&$ Kamal Ab Hamid ${ }^{1}$ \\ ${ }^{1}$ College of Business, Universiti Utara Malaysia, Malaysia \\ Correspondence: Fathi M. A. ALDamoe, College of Business, Universiti Utara Malaysia, 06010 Sintok-Kedah, \\ Malaysia. Tel: 6-017-544-3825. E-mail: ft7712@yahoo.com
}

Received: December 12, 2012 Accepted: December 21, 2012 Online Published: April 24, 2013

doi:10.5539/par.v2n1p29

URL: http://dx.doi.org/10.5539/par.v2n1p29

\begin{abstract}
The business world is concerned with improvement of organizational performance. Consequently, Human Resource Management (HRM) practices outcome on organizational performance has been the major concern of the previous scholars. Therefore, any organization that fails to improve its performance would not be able to meet up with trends in achieving competitive advantages. Accordingly, the aim of this study is to elaborate on the effect of HRM practices outcome on organizational performance in Libyan firm. From the literature scrutiny, this paper wraps up that HRM practices such as rewards and compensations as well as, performance appraisal are the HRM practices that improve organizational performance within the organization.
\end{abstract}

Keywords: organizational performance, HRM practices, performance appraisal, Libya

\section{Overview of HRM Practice and Organizational Performance}

The outcome of HRM Practices on organizational performance has been given different perceptions, predominantly on the relationship between HRM practices and their effect on organizational performance. The organization is implementing proactive HRM practices and in order to capitalize on the strength of this critical asset for sustained competitive advantage in today's knowledge economy. Guest (1997). Delaney and Huselid (1996), identified HRM practices, this has been the area of focus in this study. HRM practices that affect organizational performance are in relation to human resource planning, performance appraisal; reward and compensation, (Guest, 1997, Delaney \& Huselid, 1996). In reality, rewards leads to employees' motivation, commitments, satisfactions and opportunity to participate in the organizational activities and eventually will lead to organizational performance (Katou, 2008). Organizational performance that this study considered is mainly HRM outcomes such as employee relation and employee satisfaction.

\section{Literature Review}

\subsection{Organizational Performance}

Organizational performance is defined as effectiveness, efficiency, development, satisfaction, innovation and quality (Katou, 2008) Also, Ali, Zairi and Mahat (2006) developed a model of organizational performance comprises of employee satisfaction and the employee's performance. Nevertheless, both internal and external factors are prerequisite in measuring performance since organization depends on them for survival as well as business continuity (Mahmood \& Mann, 1991). Based on the review of previous research, this study operationalized organizational performance using a small number of of the performance indicators for organizational performance such as, employee satisfaction, employee relations.

\subsubsection{Employee Relations}

There are few studies on employee relations when developing countries are concerned (Budhwar, 2003) Although, most of the scholars on employee relations are basically from western world due to the multinational companies in mostly the developing countries and since it enables to manage the global age is very important (Budhwar \& Debra, 2001; Schuler et al., 2002). Thus, the relationship between employers, employees need to be cordial for effective communication and efficient performance. Also, the only avenue for improved productivity and organizational growth is where employee relations are well organized and suitable for the employee. Therefore, employee relation is defined as a situation where there is cordial relationship between the employers and the employees. The various benefit organizations derive from employee relations are numerous among them are: (1) It 
assists organizations the ability to maintain healthy employer-employee relationships. (2) It helps to tackle and administer workplace conflict, employers minimize potentially disruptive behavior. (3) The employer is able to identify and avoid crisis ahead of time also helps employees focus on their professional development, and support organizational goals and (4) It promotes a culture that recognizes and takes into account the interests and well-being of employees.

\subsubsection{Employee Satisfaction}

Employee satisfaction could be defined as the level at which employees love their jobs (Spectar, 1997; Antoncic \& Antoncic, 2011). When an employee's derives satisfaction on their job, the manifestation is that it will steer them to increase production, services rendered, there will be organizational growth and in returns the employees that are rewarded both in cash and in kind for instance, rewards and incentives, promotion will work towards the organizational performance (Miskell \& Miskell, 1994; Pierce \& Newstrom, 1980; Mulej, 1986; Christensen \& Staines, 1990).

\section{Human Resource Management Practices}

Human resource management practices are the tools influencing organizations to increase in its performance. The subsections 3.1-3.3 below expatiate on the HRM practices.

\subsection{Human Resource Planning}

Empirical research shows that the establishment of well-defined organizational goals and objectives influence or shape employee retention and job productivity. For instance Kim et al (2005) cited in Morncaz, Zhao \& Kay (2009) found that organizational direction and support had a major impact on employee job satisfaction and overall commitment to the organization. In much the same way, results from another empirical study indicates that perceived organizational support strongly influences job satisfaction and employees' commitment to their organizations (Susskind et al., 2000).

\subsection{Performance Appraisal}

The term performance appraisal process indicates an activity that ensures mutual understanding between the subordinate and the supervisor through the process of evaluating directly the subordinate job specific performance priorities and expectations, communication, and assigned responsibilities. The activity of performance appraisal is also a process of providing episodic and scheduled feedback that seeks to enhance teamwork and promote greater efficiencies and abilities. Generally, the performance appraisal activity is utilized by management to help develop and nurture subordinates within their organizations and in their supply chain partners. In a way appraisals can enhance job performance by focusing and emphasizing on organizational communication and its shared values and objectives. This process also systematically spells out job duties and responsibilities as they evolve over time. Appraisals are generally regarded as useful because they add value to the organization. However, the main objective of the performance appraisal process is its emphasis on subordinate or employee job performance. Through appraisals decision makers can also set goals and continuously support employees to improve their work output. It is no wonder then that the critical functions of performance appraisal include deciding who should be promoted, given a pay raise and so forth (Murphy et al, 1995). Similarly, compensation and salary decisions may depend primarily on performance appraisals. One should note that salary satisfaction is one of the key factors that shape job performance. It may also show proof of the weaknesses of the existing performance management system. It should be highlighted that superior results or performance can be attained and sustained within organizations by individuals or groups. Thus, inter-team and inter-organizational competition can be harnessed to stimulate contribution to staff improvement schemes.

In fundamental nature, performance appraisal is premised on recognizing attainment of certain objectives belonging to a specific job within a given time period. Moreover, this activity plays a crucial function in shaping the perception of subordinates about self and about their contribution to the realization of organizational goals. In a study, Bdernardin and Russel (1993) posited that broader communication of policies on performance appraisal within organizations is critical to make subordinates understand their specific functions in organizations. Performance appraisal has a positive relationship with organizational performance because client- based performance appraisal enhances quality and productivity, firm performance and increase subordinates commitment (Lee \& Lee 2007; Sang, 2005; Rahman, 2006). Likewise, Brown and Hewood (2005) posited that the process of performance appraisal system has a positive association or relationship with enhanced productivity of firms. For Cook and Crossman (2004) the relationships formed between employees and supervisors during the process of performance appraisal strengthens the relationships of the players involved. From the above discussion, 
performance appraisal is an important instrument to base career development, recognition, and promotion of employees (Larsson et al. 2007).

\subsection{Reward and Compensation}

The effective compensation and reward process enhances productivity, the quality of goods and services, improves subordinates' behavior, and decreases accident rates in organizations, thereby improving organizational performance (Delaney \& Huselid, 1996; Chiu et al., 2002; Dreher \& Dougherty, 2005, Jyothi \& Venkatesh, 2006). Rewards and Compensation shape employees' behavior and performance output, and encourages retention of talented personnel. Certainly, employee competencies improve organizational performance and by inference enhance effectiveness and encompasses all forms of monetary returns and related services provided to subordinates or employees (Milkovich \& Newman,1999). In support of this, Mathis and Jackson (2004) posited that a balanced, transparent and competitive reward and compensation system influence the retention of talents. Similarly, Dreher \& Dougherty (2005) conclude that a reward-based approach functions as the driver of team and individual performance in organizations while Chiu et al., (2002) argued that rewards and compensation considerably affect organizational outcomes. From the above discussion, rewards and compensations enhance retention of employees with the best talents (Mathis and Jackson,2004) for efficiency within the organization. Thus, based on literature review, the proposed research model is presented in Figure 1 below:

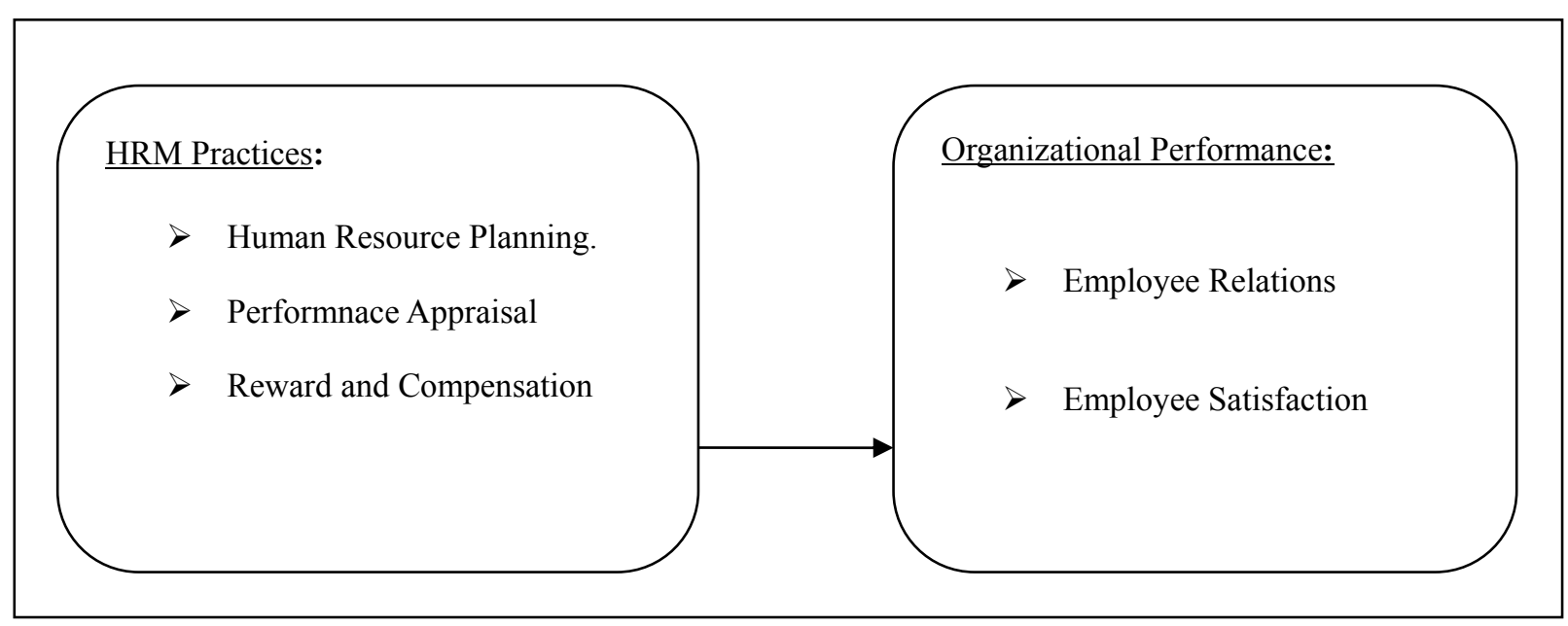

Figure 1. HRM practices on organizational performance model

\section{Conclusion}

This paper discusses human resource management practices impact on organizational performance in Libyan Firm The discussion is based on the benefits of HRM practices on organizational performance among Libyan Firms. It also presents a model that can enhance organizational performance. The ability of the organization to improve performance through the unique attributes of human resource management, reward and compensation, avails them of business continuity and the ability to have a competitive edge over other firms cannot be underestimated especially when the business activities are now towards a global world.

\section{References}

Allison, J. R. (2009). Staff selection: What's important for out-of-school time programs? Child trends 4301 Connecticut avenue NW suite 350, Washington, 202-522

Batt, R. (2002). Managing customer services: Human resource practices, quit rates, and sales Growth. Academy of Management Journal, 45, 587-597. http://dx.doi.org/10.2307/3069383

Bitner, M. J., \& Zeithaml, V. A. (2004). Service marketing. New York: McGraw Hill.

Blair, D., \& Sisakhti, R. (2007, August). Sales training: what makes it work"? T+D Magazine. Retrieved from www.astd/publication/TD Magazine/2007_pdf/August/0708_ExecSum.htm

Boisnier, A., \& Chatman, J. (2002). The role of subcultures in agile organizations. In R. Petersen, \& E. Mannix (Eds.), Leading and managing people in Dynamic organizations (pp. 87-114). New Jersey: Lavrence Eribrum Association. 
Boselie, P., Dietz, G., \& Boon, C. (2005). Commonalities and contradictions in HRM and performance research. Human Resource Management Journal, 15(3), 67-94. http://dx.doi.org/10.1111/j.1748-8583.2005.tb00154.x

Boselie, P., Paauwe, J., \& Jansen, P. (2001). Human resource management and performance: Lessons from the Netherlands. International Journal of Human Resource Management, 12, 1107-1125. http://dx.doi.org/10.1080/09585190110068331

Bowen, D. E., \& Ostroff, C. (2004). Understanding HRM-firm performance linkages: The role of the "Strength" of the HRM system". Academy of Management Review, 29(2), 203-221. http://dx.doi.org/10.5465/AMR.2004.12736076

Budhwar, P. S. (2003). Employment relations in India. Employee Relations, 25(2), 132-148. http://dx.doi.org/10.1108/01425450310456442

Budhwar, P., \& Debra, Y. (2001). Introduction: HRM in developing countires. In P. Budwar, \& Y. Debra (Eds), HRM in developing Countries (pp. 1-15). London: Routledge.

Bryman, A. (2004). Social research methods (2nd ed.). New York, NY: Oxford University Press. http://dx.doi.org/10.1557/PROC-818-M1.10.1

Chang, P. L., \& Chen, W. L. (2002). The effect of human resource management practices on firms performance: Empirical evidence from high-tech firms in Taiwan. International Journal of Management, 19(4), 622-631.

Campion, M. A., Mumford, T. V., Morgeson, F. P., \& Hahrgang, J. D. (2005). Work redesign: Eight obstacles and opportunities. Human Resource Management, 44(4), 367-390. http://dx.doi.org/10.1002/hrm.20080

Cascio, W. F. (2006). Managing human resource: Productivity, quality of work life, profits. New Delhi: Tata McGraw-Hill.

Dyer, L., \& Reeves, T. (1995). Human resource strategies and firm performance: What do we know and where do we need to go? Paper presented at the 10th World Congress of the International Industrial Relations Association. Washington, DC.

Guest, D. E. (1997). Human resources management and performance: A review and research agenda. International Journal of Human Resources Management, 8(3), 263-276. http://dx.doi.org/10.1080/095851997341630

Guest, D. E. (2001). Human resource management: when research confronts theory. International Journal of Human Resource Management, 12, 1092-1106. http://dx.doi.org/10.1080/09585190110067837

Hoskisson, R. E., Eden, L., Lau, C. M., \& Wright, M. (2000). Strategy in emerging Economics. Academy of Management Journal, 43(3), 249-267. http://dx.doi.org/10.2307/1556394

Hsu, Y. R., \& Leat, M. (2000). A study of HRM and recruitment and selection policies and practices in Taiwan. International Journal of Human Resource Management, 11(2), 413-435. http://dx.doi.org/10.1080/095851900339936

Hunter, E. J., \& Schmidt, L. F. (1982). Ability tests: economic benefits versus.

Huselid, M. A. (1995). The impact of human resource management practices on turnover, Productivity and corporate financial performance. Academy of Management Journal, 38, 653-672. http://dx.doi.org/10.2307/256741

Powell, T. C. (1992). Organizational alignment as a competitive advantage. Strategi Management Journal, 13, 119-134. http://dx.doi.org/10.1002/smj.4250130204

Katou, A. A., \& Budhwar, P. S. (2006). The effect of human resource management policies on organizational performance in Greek manufacturing firms. Thunderbird International Business Review, 49(1), 1-35. http://dx.doi.org/10.1002/tie.20129

Myloni, B., Harzing, A. W. K., \& Mirza, H. (2004). Host country specific factors and the transfer of human resource management practices in multinational companies. International Journal of Manpower, 25(6), 518-534. http://dx.doi.org/10.1108/01437720410560424

Schuler, R. S, Budwar, P., \& Florkowski, G. W. (2002). International human resource management. 'review and critique'. International Journal of Management Reviews. 4(1), 41-47. http://dx.doi.org/10.1111/1468-2370.00076

Whitener, E. M. (2001). Do "high commitment" human resource practices affect employee commitment? A cross-level analysis using hierarchical linear modeling. Journal of Management, 27, 515-535. http://dx.doi.org/10.1177/014920630102700502 